\title{
HUBUNGAN ANTARA RASA KOMUNITAS DAN KOMITMEN ORGANISASI DENGAN KOHESIVITAS KELOMPOK PADA ANGGOTA SEKAA TERUNA-TERUNI DI
} BADUNG

\author{
Luh Putu Ela Vilayanti dan Supriyadi \\ Program Studi Psikologi, Fakultas Kedokteran, Universitas Udayana \\ e.vilayanti@gmail.com
}

\begin{abstract}
Abstrak
Masa remaja merupakan masa mengembangkan potensi diri sehingga diperlukan wadah untuk remaja mengembangkan kemampuan dirinya agar menjadi remaja yang lebih baik. Provinsi Bali memiliki suatu perkumpulan bagi remaja yang disebut dengan Sekaa Teruna-Teruni. Sekaa Teruna-Teruni merupakan kumpulan pemuda-pemudi yang berkembang atas dasar kesadaran dan tanggung jawab sosial. Kegiatan dan program kerja Seka Teruna-Teruni agar menjadi sukses diperlukan rasa komunitas, komitmen organisasi dan kohesivitas kelompok antar anggota, akan tetapi fakta yang terjadi pada beberapa anggota Sekaa Teruna-Teruni yaitu kehadiran anggota yang sedikit, keaktifan yang kurang, kegiatan yang kurang menarik, anggota banyak yang merantau, sibuk dengan pekerjaan rumah serta terjadinya kelompok-kelompok kecil. Penelitian ini bertujuan untuk mengetahui hubungan antara rasa komunitas dan komitmen organisasi dengan kohesivitas kelompok pada anggota Sekaa Teruna-Teruni. Subjek yang digunakan dalam penelitian ini adalah anggota Sekaa Teruna-Teruni di Badung yang berjumlah 99 orang. Instrumen dalam penelitian ini yaitu skala rasa komunitas, skala komitmen organisasi dan skala kohesivitas kelompok yang telah diuji validitas dan reliabilitasnya. Hipotesis dari penelitian ini adalah terdapat hubungan antara rasa komunitas dan komitmen organisasi dengan kohesivitas kelompok pada anggota Sekaa Teruna-Teruni di Badung. Hasil analisis regresi berganda menunjukkan bahwa ketiga variabel tersebut berhubungan secara signifikan $(\mathrm{p}<0.05)$ dan diyakini bahwa variabel rasa komunitas dan komitmen organisasi dapat memprediksi kohesivitas kelompok. Varian rasa komunitas dan komitmen organisasi dapat menjelaskan varian kohesivitas kelompok sebesar 72,3\%, sehingga dapat disimpulkan bahwa rasa komunitas dan komitmen organisasi dapat meningkatkan kohesivitas kelompok pada anggota Sekaa Teruna-Teruni.
\end{abstract}

Kata kunci: kohesivitas kelompok, rasa komunitas, komitmen organisasi, Sekaa Teruna-Teruni

\begin{abstract}
Adolescence is a period of developing self-potential, so a place is needed for adolescents to develop their ability to become better teenagers. Bali, has a youth association called Sekaa Teruna-Teruni. It is a group of young people growing on the basis of social awareness and responsibility. In order to make the work program successfully complete, it requires a sense of community, organizational commitment and group cohesiveness among members, but the facts that happened to some members of the Sekaa Terun-Teruni are the presence of a few members, less liveliness, uninteresting activities, many members migrate, busy with homework and form small groups. This study aimed to determine the relationship between a sense of community and organizational commitment with group cohesiveness in members of Sekaa Teruna-Teruni. The subjects used in this study were 99 members of Sekaa Teruna-Teruni. The instruments in this study were the scale of community sense, organizational commitment, and group cohesiveness that had been examined for their validity and reliability. The hypothesis of this study is that there is a relationship between a sense of community and organizational xommitment with group cohesiveness in members of Sekaa Teruna-TEruni in Badung. The results of multiple regression analysis showed that those three variables were correlated significantly ( $p$ $<0.05$ ); and it was believed that community sense and organizational commitment of the organization could predict the group cohesiveness. The community sense and organizational commitment could explain the group cohesiveness of $72.3 \%$, so it could be concluded that they could be increase the group cohesiveness within Sekaa Teruna-Teruni members.
\end{abstract}

Keywords: group cohesiveness, community sense, organizational commitment, Sekaa Teruna-Teruni 


\section{HUBUNGAN ANTARA RASA KOMUNITAS DAN KOMITMEN ORGANISASI DENGAN KOHESIVITAS KELOMPOK}

\section{LATAR BELAKANG}

Masa remaja merupakan masa yang aktif dalam mencari identitas dan mengembangkan potensi diri. Masa remaja dimulai dari usia 10 sampai 13 tahun dan berakhir pada usia 18 sampai 22 tahun (Santrock, 2007). Menurut Hurlock (1980), pada masa remaja merupakan periode perubahan bagi remaja tidak hanya perubahan fisik namun juga terjadinya perubahan kematangan emosi, perubahan minat dan peran, perubahan nilai-nilai yang dianut serta keinginan akan kebebasan. Masa remaja juga disebut masa mencari identitas diri, dalam hal ini remaja akan mencari tahu tentang diri sendiri dan peran remaja di masyarakat (Hurlock, 1980).

Masa remaja juga sangat rentan akan perilaku negatif dan kejahatan, salah satu alasannya karena remaja menganggap diri sudah dewasa. Hurlock (1980), menyatakan masa remaja sebagai ambang masa dewasa yang berarti remaja mengalami kebingungan atau kesulitan di dalam usaha meninggalkan kebiasaan pada usia sebelumnya dan memberikan kesan bahwa remaja tersebut hampir atau sudah dewasa. Hal tersebut tampak pada perilaku remaja yang mencoba-coba menggunakan alkohol, rokok, mengemudi dalam keadaan mabuk dan terlibat dalam perilaku seks (Papalia, Olds \& Feldman, 2008), sehingga diperlukan wadah untuk remaja bisa melatih soft skill dan mengembangkan kemampuan diri sehingga remaja yang terlibat dalam aktivitas konstruktif di waktu luang dapat menjadi remaja yang yang lebih baik dan menghasilkan keuntungan dalam jangka panjang (Larson dalam Papalia dkk, 2008). Salah satu provinsi yang memiliki wadah dalam mengembangkan kreativias remaja yaitu provinsi Bali. Provinsi Bali merupakan sebuah provinsi yang memiliki organisasi yang terdiri dari beberapa kepala keluarga yang disebut dengan banjar (Abu, 1981). Banjar terlihat pasif apabila yang terlibat hanya bapak-bapak dan ibu-ibu yang terlihat dari aktivitas nyayah di banjar, oleh karena itu setiap banjar adat di Bali memiliki kelompok pemuda-pemudi yang disebut dengan Sekaa Teruna-Teruni. Sekaa yang dalam bahasa Indonesia berarti kumpulan, wadah, atau organisasi, sedangkan Teruna-Teruni yang dalam bahasa Indonesia berarti pemuda pemudi, sehingga Sekaa TerunaTeruni merupakan kumpulan pemuda-pemudi yang berkembang atas dasar kesadaran dan tanggung jawab sosial (Kebudayaan Indonesia, 2014).

Remaja masuk dalam keanggotaan Sekaa TerunaTeruni berusia 16 tahun atau telah bersekolah di Sekolah Menengah Atas (SMA) (Kebudayaan Indonesia, 2014). Sekaa Teruna-Teruni tersebut memiliki beberapa program kerja yang harus melibatkan semua anggota, anggota yang terlibat berada dalam keanggotaan banjar. Sekaa Teruna-Teruni juga memiliki struktur yang terdiri dari pengurus inti yaitu ketua, wakil ketua, sekretaris, bendahara dan bebarapa ketua departemen atau bidang. Kegiatan Sekaa Teruna-Teruni yang terlihat menonjol diantaranya, pawai ogoh-ogoh, kerja bakti, rapat rutin. Kegiatan dari program kerja Sekaa Teruna-Teruni akan berjalan sukses apabila terdapat keaktifan dan kerja sama antar anggota, tidak hanya pada program kerja Seka TerunaTeruni juga berperan sebagai sarana sosial yang menjadi wadah bagi para anggotanya untuk bertukar pikiran, berinteraksi, serta mewujudkan ide-ide demi kemajuannya bersama (Sintari, 2015). Sekaa Teruna-Teruni yang merupakan suatu organisasi yang bertugas membantu (ngayah) pada kegiatan-kegiatan orang tua di banjar, oleh karena itu Sekaa Teruna-Teruni menjadi kelompok multifungsi di banjar (Astika dalam Pitana, 1994).

Kesuksesan suatu kegiatan Sekaa Teruna Teruni tentunya membutuhkan keterlibatan dari seluruh anggota Sekaa Teruna-Teruni, oleh sebab itu para anggota sudah seharusnya memiliki rasa komunitas dan komitmen terhadap Sekaa Teruna-Teruninya agar terlihat kohesif. Akan tetapi pada studi pendahuluan yang dilakukan kepada beberapa perwakilan Sekaa Teruna-Teruni, fakta yang terjadi yaitu berdasarkan hasil studi pendahuluan dengan mantan anggota Sekaa Teruna-Teruni yang bernama PY, jaman dahulu pemuda-pemudi yang tergabung dalam Sekaa Teruna Teruni sangat aktif dalam kegiatan di desa, seperti mengikuti perlombaan antar desa dengan bangga membawa piala-piala hasil dari perlombaan tersebut, jaman sekarang hanya ada beberapa Sekaa Teruna-Teruni yang masih aktif mengikuti lomba-lomba (Vilayanti, 2016). Hal tersebut salah satu faktor yang memengaruhinya adalah banyaknya anggota Sekaa Teruna-Teruni yang menuntut ilmu ke luar daerah dan bekerja dengan waktu yang tidak tentu. Beberapa pemuda-pemudi yang tidak memiliki kegiatan juga tidak aktif dalam Sekaa Teruna-Teruninya (Vilayanti, 2016).

Hasil studi pendahuluan dengan salah satu anggota Sekaa Teruna-Teruni menyebutkan bahwa saat subjek kembali ke daerah bersamaan dengan ada kegiatan Sekaa TerunaTeruni, belum dapat dipastikan subjek akan aktif kembali di Sekaa Teruna-Teruni. Alasan subjek tidak aktif lagi adalah kurang bisa menyesuaikan diri kembali di banjar, temanteman subjek ada yang sudah bekerja oleh sebab itu subjek takut jika subjek sendiri dari angkatannya yang aktif. Alasan lainnya adalah subjek malu karena tidak pernah ikut kegiatan sebelumnya (Vilayanti, 2016). Studi pendahuluan yang dilakukan dengan DW, juga menyebutkan bahwa anggota yang tidak merantau dan tidak bekerja juga memiliki permasalahan yang sama dengan keaktifan di Sekaa TerunaTeruni. Alasan dari para anggota yaitu sibuk sekolah, banyak tugas sekolah atau kampus, teman-temannya tidak ada yang ke banjar (Vilayanti, 2016).

Berdasarkan observasi peneliti pada tanggal 5 Maret 2017 di media sosial belakangan ini, terdapat berbagai keluh kesah para anggota Sekaa Teruna-Teruni saat membuat ogohogoh dalam rangka menyambut hari raya pengerupukan tahun 2017, dalam media tersebut terdapat anggota yang 
memposting foto. Foto berisi tulisan yang mengajak temanteman sesama anggota Sekaa Teruna-Teruni untuk ikut serta membuat ogoh-ogoh dan memohon kesadaran dari semua anggota (Popo Gus Popo, 2017). Hal tersebut merupakan salah satu contoh kurangnya rasa memiliki dari anggota Sekaa Teruna-Teruni terhadap kegiatan yang dilaksanakan. Kegiatan Sekaa Teruna-Teruni akan sukses jika semua anggotanya mempunyai rasa memiliki, keyakinan dan komitmen terhadap Sekaa Teruna-Teruni. Hal tersebut masuk dalam pengertian rasa komunitas (sense of community). Rasa komunitas (sense of community) adalah perasaan memiliki pada setiap anggota akan komunitas dan perasaan berharga dan berkepentiangan dalam suatu komunitas, sehingga timbul keyakinan dan komitmen untuk bersama dalam komunitas (McMillan \& Chavis, 1986). Seorang yang memiliki rasa komunitas yang baik akan mendorong individu untuk bekerja lebih baik. Asumsinya jika anggota Sekaa Teruna-Teruni memiliki rasa komunitas yang tinggi maka keberhasilan kegiatan Sekaa Teruna-Teruni tersebut tentunya akan berjalan dengan baik.

Peneliti menggunakan data sekunder salah satu Sekaa Teruna Teruni di Kecamatan Mengwi dengan melihat absensi kehadiran anggota, dari anggota yang berjumlah lebih kurang 180 orang, ketika rapat bisa dilihat kurang lebih hanya $25 \%$ yang hadir saat rapat rutin. Kedatangan anggota menjadi keluhan yang dirasakan oleh MA, yaitu ketika diberi pengumuman, rapat dimulai jam 19.00 WITA, akan tetapi anggota berdatangan pukul 20.00 WITA . Anggota yang berdatangan saat rapat tersebut rata- rata berjumlah $25 \%$ $50 \%$ dari jumlah anggota keseluruhan (Vilayanti, 2016).

Hasil penelitian Prayoga dan Herdiyanto (2014) menunjukkan bahwa perasaan memiliki pengurus subak akan kebersamaan demi mencapai komitmennya pada subak di Kecamatan Pekutatan lebih didominasi oleh rasa komunitas pengurus subak kategori sangat tinggi. Apabila pada anggota Sekaa Teruna-Teruni memiliki rasa komunitas tinggi maka rasa memilikinya akan tinggi, namun fakta yang terjadi yaitu ketika diselenggarakannya kegiatan, tidak semua anggota yang bersedia hadir untuk berpartisipasi dalam kegiatan tersebut.

Komitmen dari anggota Sekaa Teruna-Teruni menjadi faktor penting dalam menyukseskan kegiatan yang disusun oleh pengurus. Komitmen anggota dilihat dari intensitas anggota dalam mengikuti setiap kegiatan yang ada. Komitmen anggota akan terlihat ketika anggota lebih mengutamakan kegiatan Sekaa Teruna-Teruni dibandingkan dengan aktivitas pribadi. Berdasarkan hasil studi pendahuluan dengan salah satu pengurus Sekaa Teruna-Teruni yang terjadi yaitu anggota Sekaa Teruna Teruni sering menggunakan alasan sibuk dengan tugas sekolah atau pekerjaan ketika tidak hadir saat diadakan kegiatan Sekaa Teruna-Teruni (Vilayanti, 2016). Fakta tersebut bertentangan dengan pengertian komitmen berorganisasi menurut Robbins (2008), yaitu komitmen organisasi merupakan suatu keadaan di mana seorang anggota organisasi memihak pada suatu organisasi tertentu dan tujuan-tujuan organisasi serta berniat memelihara keanggotaan dalam organisasi tersebut. Komitmen yang tinggi berarti pemihakan pada organisasi yang memperkerjakannya.

Kohesivitas adalah kekuatan, baik positif maupun negatif, yang menyebabkan anggota tetap dalam kelompok (Taylor, Peplau, \& Sears, 2009). Apabila anggota saling menyukai satu sama lain, dan terikat oleh hubungan pertemanan, kepaduan akan tinggi (Paxton \& Moody dalam Taylor dkk, 2009). Menurut hasil studi pendahuluan kepada salah satu perwakilan Sekaa Teruna Teruni, subjek mengatakan jika ada perpecahan antar anggota sehingga terbentuk kumpulan geng pada anggota-anggota tersebut (Vilayanti, 2016).

Kohesivitas kelompok memberikan kontribusi yang besar pada perbaikan kerja karyawan bahkan dapat meningkatkan kinerja karyawan (Zulkifli \& Yusuf, 2015). Asumsinya jika pada anggota Sekaa Teruna-Teruni diharapkan anggota yang memiliki kohesivitas tinggi maka kinerjanya akan tinggi. Berdasarkan hasil studi pendahuluan dengan SD (2016) yang menyebutkan pada beberapa Sekaa Teruna Teruni yang memiliki kinerja tinggi pada beberapa anggota namun kohesivitasnya rendah, hal tersebut terlihat pada saat pembuatan ogoh-ogoh hanya beberapa anggota lakilaki yang memiliki kemampuan dalam mengukir saja yang aktif (Vilayanti, 2016).

Hasil studi pendahuluan dengan OA menyebutkan perbedaan pendapat sering pula menjadi perpecahan antar anggota. Hal tersebut didukung oleh pernyataan ED dalam studi pendahuluan yang menyebutkan kesenjangan antara anggota laki-laki dan perempuan juga menjadi sumber perpecahan, misalnya ketika diselenggarakan kegiatan gotong royong, pembuatan penjor, persiapan penggalian dana anggota yang lebih banyak kehadirannya adalah anggota laki-laki dibandingkan anggota perempuan. Permasalahan pada anggota Sekaa Teruna-Teruni bersumber dari program kerja yang tidak jelas dan kurang menarik serta informasi tentang jadwal kegiatan yang kurang disampaikan dengan jelas sehingga menimbulkan ketidak kompakan anggota berdasarkan jumlah kehadiran yang sedikit (Vilayanti, 2016).

Berita dari media online Antara Bali menyebutkan bahwa kabupaten Badung merupakan kabupaten yang memiliki pendapatan daerah lebih tinggi dari kabupaten lainnya (Sutika, 2016), sehingga organisasi-organisasi di Kabupaten Badung sudah seharusnya mendapat fasilitas yang lengkap. Hal tersebut tampak pada pemerintah Kabupaten Badung berkomitmen untuk tetap melestarikan seni dan budaya yang ada. Hal yang dilakukan oleh Pemerintah Kabupaten Badung dalam memfasilitasi Sekaa Teruna-Teruni yaitu mendukung kreativitas Sekaa Teruna sebagai generasi penerus yang akan melanjutkan pembangunan di Kabupaten Badung. Bentuk dukungan pemerintah bagi Sekaa TerunaTeruni di Badung yaitu memberikan bantuan materiil berupa 


\section{HUBUNGAN ANTARA RASA KOMUNITAS DAN KOMITMEN ORGANISASI DENGAN KOHESIVITAS KELOMPOK}

sumbangan dalam pembuatan ogoh-ogoh sebesar lima belas juta rupiah. Sumbangan tersebut langsung diberikan kepada masing-masing Sekaa Teruna-Teruni dan diawasi pemakaiannya (Surya, 2017). Berita online yang dilansir dari Metro Bali menyebutkan bahwa pemerintah Kabupaten Badung juga mengadakan lomba ogoh-ogoh antar Sekaa Teruna di Kabupaten Badung yang bertujuan untuk memupuk tali persaudaraan dan mempererat rasa persatuan dan kesatuan Sekaa Teruna di Kabupaten Badung serta pemerintah kabupaten Badung juga memberikan hadiah sebagai apresiasi bagi Sekaa Terun-Teruni yang dapat membuat ogoh-ogoh yang memiliki nilai kreativitas tinggi (Antara, 2017).

Asumsinya adalah jika anggota Sekaa Teruna Teruni rasa komunitasnya tinggi maka kohesivitas kelompoknya juga tinggi. Jika komitmen anggota Sekaa Teruna-Teruni tinggi maka kohesivitas kelompoknya juga tinggi. Jadi untuk menyukseskan kegiatan Sekaa Teruna Teruni sangat diperlukan partisipasi dari semua anggotanya, namun tidak semua anggota aktif dalam kegiatan Sekaa Teruna Teruni. Banyak faktor yang menjadi latar belakang tidak aktifnya beberapa anggota, oleh karena itu perlu diteliti mengenai hubungan antara rasa komunitas dan komitmen organisasi dengan kohesivitas kelompok serta apakah ketiga faktor ini juga melatarbelakangi keterlibatan anggota Sekaa TerunaTeruni di Kabupten Badung.

\section{METODE PENELITIAN}

\section{Variable dan Definisi Operational}

Variabel tergantung dalam penelitian ini adalah kohesivitas kelompok serta variabel bebas dalam penelitian ini adalah rasa komunitas dan komitmen orgnisasi. Definisi operasional dari masing-masing variabel penelitian adalah sebagai berikut:

\section{Kohesivitas Kelompok}

Rasa komunitas merupakan perasaan yang dimiliki dalam kebersamaan antar anggota kelompok, tingginya kohesivitas kelompok berarti tiap anggota kelompok saling berinteraksi antar satu sama lain, memperoleh tujuan mereka, saling membantu tiap pertemuan dan apabila anggota kelompok tidak kompak, maka tiap anggota kelompok akan saling tidak menyukai satu sama lain dan akan menimbulkan perbedaan pendapat. Semakin tinggi skor yang diperoleh, maka semakin tinggi taraf kohesivitas kelompok yang dimiliki subjek.

\section{Rasa Komunitas}

Rasa komunitas merupakan perasaan memiliki pada tiap anggota komunitas serta perasaan berharga dan saling memiliki kepentingan dalam suatu komunitas, sehingga anggota komunitas memiliki keyakinan dan komitmen untuk bersama dalam komunitas. Semakin tinggi skor yang diperoleh, maka semakin tinggi taraf rasa komunitas yang dimiliki subjek.

\section{Komitmen Organisasi}

Komitmen organisasi adalah ikatan psikologis individu pada organisasi termasuk keterlibatan kerja, loyalitas dan keyakinan terhadap nilai organisasi, anggota yang memihak organisasi tertentu serta memiliki keinginan untuk mempertahankan keanggotaan dalam organisasi tersebut. Semakin tinggi skor yang diperoleh, maka semakin tinggi taraf komitmen organisasi yang dimiliki subjek.

\section{Responden}

Populasi peneltian ini adalah anggota Sekaa TerunaTeruni di Kabupaten Badung yang berjumlah 99 orang. Karakteristik populasi dalam penelitian ini antara lain:

1. Anggota Sekaa Teruna-Teruni yang berusia 16 tahun sampai dengan 22 tahun.

2. Terdaftar dalam banjar-banjar yang terdapat di kabupaten Badung.

Teknik pengambilan sampel pada penelitian ini adalah teknik cluster sampling one stage, yaitu stage adalah membagi populasi menjadi beberapa kelompok dengan satu tahap, teknik ini dilakukan apabila populasi sangat luas (Nazir, 1999). Sebanyak 535 Sekaa Teruna-Teruni di Kabupaten Badung dirandom untuk menentukan Sekaa Teruna-Teruni menjadi sampel dalam penelitian ini. Skala yang disebarkan pada proses pengambila data adalah sebanyak 100 skala, namun hanya 99 skala yang diisi dengan lengkap dan dapat dianalisis.

\section{Alat Ukur}

Alat ukur penelitian ini menggunakan skala kohesivitas kelompok, skala rasa komunitas, dan skala komitmen organisasi. Skala kohesivitas kelompok disusun oleh peneliti berdasarkan aspek-kohesivitas kelompok menurut Forsyth (2010), skala asa komunitas dimodifikasi oleh peneliti dari penelitian yang dilakukan Prayoga (2014) berdasarkan aspek-aspek rasa komunitas menurut McMillan dan Chavis (1986), dan skala kohesivitas kelompok juga disusun oleh peneliti berdasarkan aspek-aspek kohesivitas kelompok menurut Allen dan Meyer, (1997).

Skala kohesivitas kelompok terdiri dari 28 aitem pernyataan, skala rasa komunitas terdiri dari 26 aitem pernyataan, dan skala dukungan sosial terdiri dari 31 aitem pernyataan. Skala ini terdiri dari pernyataan positif (favorable) dan pernyataan negatif (unfavorable) dengan empat pilihan jawaban yaitu Sangat Sesuai (SS), Sesuai (S), Tidak Sesuai (TS), dan Sangat Tidak Sesuai (STS).

Menurut Azwar (2014), suatu alat tes dinyatakan memiliki validitas yang baik jika alat tersebut mampu memberikan hasil ukur yang sesuai dengan maksud dilakukannya pengukuran. Pada penelitian ini, uji validitas konstruk dilakukan dengan melihat koefisien korelasi item 
total sebesar 0,30 (Azwar, 2014). Teknik pengukuran reliabilitas yang digunakan pada penelitian ini adalah Alpha Cronbach dimana konstruk atau variabel dapat dikatakan reliabel jika nilai Alpha Cronbach lebih besar dari 0,60 (Ghozali, 2005).

Penyebaran skala uji coba alat ukur dilaksanakan pada tanggal 24 Januari sampai 27 Januari 2017 yang diberikan kepada Sekaa Teruna-Teruni Dharma Laksana banjar Jumpayah. Hasil uji validitas skala kohesivitas kelompok menunjukkan nilai koefisien korelasi aitem total yang bergerak dari 0,316 - 0,803. Hasil uji reliabilitas skala kohesivitas kelompok menunjukkan koefisien Alpha Cronbach sebesar 0,928 yang berarti bahwa skala ini mampu mencerminkan $92,80 \%$ variasi skor murni subjek, sehingga dapat disimpulkan bahwa skala kohesivitas kelompok layak digunakan sebagai alat ukur untuk mengukur taraf kohesivitas kelompok subjek.

Hasil uji validitas skala rasa komunitas menunjukkan nilai koefisien korelasi aitem total yang bergerak dari 0,316 0,622 . Hasil uji reliabilitas skala rasa komunitas menunjukkan koefisien Alpha Cronbach sebesar 0,893 yang berarti bahwa skala ini mampu mencerminkan $89,30 \%$ variasi skor murni subjek, sehingga dapat disimpulkan bahwa skala rasa komunitas layak digunakan sebagai alat ukur untuk mengukur taraf rasa komunitas subjek.

Hasil uji validitas skala komitmen organisasi menunjukkan nilai koefisien korelasi aitem total yang bergerak dari 0,303 - 0,694. Hasil uji reliabilitas skala komitmen organisasi menunjukkan koefisien Alpha Cronbach sebesar 0,927 yang berarti bahwa skala ini mampu mencerminkan 92,70\% variasi skor murni subjek, sehingga dapat disimpulkan bahwa skala komitmen organisasi layak digunakan sebagai alat ukur untuk mengukur taraf komitmen organisasi subjek.

\section{Teknik Analisis Data}

Uji hipotesis dilakukan apabila data peneletian telah melewati syarat uji asumsi yaitu uji normalitas, uji linearitas, uji multikolinearitas dan uji heteroskedastisitas. Uji normalitas pada penelitian ini menggunakan uji Kolmogorov Smirnov, uji linearitas dilakukan dengan menggunakan uji Lagrange Multiplier, uji multikolinearitas dilakukan dengan melihat nilai Variance Inflation Factor (VIF) dan nilai Tolerance dan uji heteroskedastisitas dilakukan dengan menggunaka uji Glesjer. Setelah melakukan uji asumsi, data penelitian dianalisis dengan menggunakan metode analisis regresi berganda untuk menguji hipotesis mayor dan hipotesis minor. Analisis data dilakukan dengan menggunakan bantuan program SPSS 22.0 for Windows.

\section{HASIL PENELITIAN}

\section{Karakteristik Subyek}

Berdasarkan data karakteristik subjek, diperoleh bahwa total subjek berjumlah 99 orang dengan jenis kelamin perempuan sebanyak 45 orang dan laki-laki sebanyak 54 orang. Mayoritas subjek penelitian adalah berusia 17 dan 21 tahun yaitu masing-masing sebanyak 20 orang, dan mayoritas berasal dari Banjar Perang yaitu sebanyak 32 orang. Mayoritas subjek berpendidikan terakhir Sekolah Menengah Pertama (SMP) yaitu sebanyak 38 orang dan mayoritas subjek telah bergabung dalam Sekaa Teruna Teruni selama 1 tahun yaitu sebanyak 23 orang.

\section{Deskripsi Data Penelitian}

Hasil deskripsi penelitian variabel penyesuaian diri, kecerdasan emosional dan dukungan sosial dapat dilihat pada table1.

\begin{tabular}{lcccccccc}
$\begin{array}{l}\text { Tabel 1. } \\
\text { Deskripsi Data Penelitian }\end{array}$ & \multicolumn{10}{l}{} \\
\hline Variabel & $\mathbf{N}$ & $\begin{array}{c}\text { Mean } \\
\text { Teoretis }\end{array}$ & $\begin{array}{c}\text { Mean } \\
\text { Empiris }\end{array}$ & $\begin{array}{c}\text { Std. } \\
\text { Deviasi } \\
\text { Teoretis }\end{array}$ & $\begin{array}{c}\text { Std. } \\
\text { Deviasi } \\
\text { Empiris }\end{array}$ & $\begin{array}{c}\text { Sebaran } \\
\text { Teoretis }\end{array}$ & $\begin{array}{c}\text { Sebaran } \\
\text { Empiris }\end{array}$ & Nilai t \\
\hline $\begin{array}{c}\text { Kohesivitas } \\
\text { Kelompok } \\
\quad \text { Rasa }\end{array}$ & 99 & 70 & 90,72 & 14 & 8,870 & $28-112$ & $74-111$ & $\begin{array}{c}101,763 \\
(p=0,000)\end{array}$ \\
$\begin{array}{c}\text { Komunitas } \\
\text { Komitmen } \\
\text { Organisasi }\end{array}$ & 99 & 77 & 84,20 & 13 & 7,191 & $26-104$ & $62-100$ & $\begin{array}{c}116,503 \\
(p=0,000)\end{array}$ \\
\hline
\end{tabular}

Hasil deskripsi statistik data penelitian pada tabel 1 menunjukkan bahwa variabel kohesivitas kelompok memiliki mean teoretis sebesar 70 dan mean empiris sebesar 90,72 dengan perbedaan sebesar 20,72. Hal ini menandakan subjek penelitian memiliki taraf kohesivitas kelompok yang tinggi karena nilai mean empiris lebih besar daripada mean teoretis (90,72 > 70). Berdasarkan penyebaran frekuensi, subjek dalam penelitian ini menghasilkan rentang skor antara 74 sampai dengan 111, serta $100 \%$ subjek memiliki skor diatas mean teoretis.

Hasil deskripsi statistik data penelitian pada tabel 1 menunjukkan bahwa variabel rasa komunitas memiliki memiliki mean teoretis sebesar 65 dan mean empiris sebesar 84,20 dengan perbedaan sebesar 19,20. Hal ini menandakan subjek penelitian memiliki taraf rasa komunitas yang tinggi karena nilai mean empiris lebih besar daripada mean teoretis $(84,20>65)$. Berdasarkan penyebaran frekuensi, subjek dalam penelitian ini menghasilkan rentang skor antara 62 sampai dengan 100, serta $98 \%$ subjek memiliki skor diatas mean teoretis.

Hasil deskripsi statistik data penelitian pada tabel 1 menunjukkan bahwa variabel komitmen organisasi memiliki memiliki mean teoretis sebesar 77,5 dan mean empiris sebesar 99,75 dengan perbedaan sebesar 22,25. Hal ini menandakan subjek penelitian memiliki taraf komitmen organisasi yang tinggi karena nilai mean empiris lebih besar daripada mean teoretis $(99,75>77,5)$. Berdasarkan penyebaran frekuensi, 


\section{HUBUNGAN ANTARA RASA KOMUNITAS DAN KOMITMEN ORGANISASI DENGAN KOHESIVITAS KELOMPOK}

subjek dalam penelitian ini menghasilkan rentang skor antara 72 sampai dengan 121, serta 99\% subjek memiliki skor diatas mean teoretis.

\section{Uji Asumsi}

Tabel 2.

Hasil Uji Normalitas Variabel Penelitian dengan Data Residual

\begin{tabular}{lc}
\hline & Unstandardized Residual \\
\hline $\mathrm{N}$ & 99 \\
Test Statisctic & 0,084 \\
Asymp. Sig. (2-tailed) & $0,083^{\mathrm{c}}$ \\
\hline
\end{tabular}

Berdasarkan hasil uji normalitas data penelitian pada tabel 22, uji normalitas dalam penelitian ini menggunakan nilai residual dari ketiga variabel sehingga memperoleh nilai test statistic sebesar 0,084 dengan signifikansi sebesar 0,083 ( $p>0,05)$. Hal ini menunjukkan bahwa data residual variabel berdistribusi

normal.

Tabel 3.

\begin{tabular}{lccccc}
\hline & Uji Linearitas Data Penelitian & & & \\
& $\mathbf{R}$ & R Square & $\begin{array}{l}\text { Adjusted } \boldsymbol{R} \\
\text { Square }\end{array}$ & $\begin{array}{l}\text { Std. Error of the } \\
\text { Estimate. }\end{array}$ \\
\hline Rasa Komunitas2 & 0,011 & 0,000 & & $-0,010$ & 4,64120343 \\
Komitmen & 0,014 & 0,000 & & $-0,010$ & 4,64104554 \\
Organisasi2 & & & & & \\
\hline
\end{tabular}

Uji linieritas dilakukan untuk mengetahui apakah ada hubungan yang linier antara variabebebas dengan variabel tergantung. Berdasarkan hasil uji lineritas data pada tabel 3, kedua variabel menunjukkan nilai $\mathrm{R} 2$ ( $\mathrm{R}$ Square) sebesar 0,000 dengan jumlah subjek 99, maka besarnya c2 hitung = (n*R2) yaitu 0,000. Nilai ini dibandingkan dengan c2 tabel didapat nilai c2 tabel 5,09. Oleh karena nilai c2 hitung lebih kecil dari c2 tabel maka dapat disimpulkan bahwa model yang benar dari kedua variabel adalah adalah model linier.

Tabel 4.

\begin{tabular}{lccl}
\multicolumn{1}{c}{ Uji Multikolonieritas Data Penelitian } & & \\
\hline Variabel & Tolerance & $\begin{array}{c}\text { Variance Inflation } \\
\text { Factor (VIF) }\end{array}$ & Keterangan \\
\hline Rasa Komunitas & .306 & 3.272 & $\begin{array}{l}\text { Tidak terjadi } \\
\text { multikolonieritas } \\
\text { Komitmen Organisasi }\end{array}$ \\
\hline
\end{tabular}

Uji multikolonieritas digunakan untuk mengetahui apakah terdapat korelasi antara variabel bebas satu dengan variabel bebas lainnya. Model regresi dianggap baik ketika variabel bebas tidak memiliki korelasi yang tinggi dengan variabel bebas lainnya. Hal tersebut dapat dilihat dari nilai VIF kurang dari 10 dan nilai Tolerance yang lebih besar dari 0,1 (Ghozali, 2005). Tabel 4 dapat dinyatakan bahwa tidak terjadi multikolonieritas diantara kedua variabel bebas penelitian yaitu rasa komunitas dan komitmen organisasi. Hal ini ditunjukkan dengan nilai VIF sebesar 3,272 (dibawah 10) dan nilai tolerance sebesar 0,306 (diatas 0,1).

Tabel 5.

Hasil Uji Heteroskedastisitas

\begin{tabular}{|c|c|c|c|c|c|}
\hline \multirow[t]{2}{*}{ Model } & \multicolumn{2}{|c|}{$\begin{array}{l}\text { Unstandardized } \\
\text { Coefficients }\end{array}$} & \multirow{2}{*}{$\begin{array}{c}\begin{array}{c}\text { Standardized } \\
\text { Coefficients } \\
\text { Beta }\end{array} \\
\end{array}$} & \multirow[t]{2}{*}{$t$} & \multirow[t]{2}{*}{ Sig. } \\
\hline & B & Std. Error & & & \\
\hline Konstan & 6.120 & 3.719 & & 1.645 & .103 \\
\hline Rasa Komunitas & -.084 & .080 & -.194 & -1.056 & .294 \\
\hline Komitmen Organisasi & .044 & .058 & .138 & .754 & .453 \\
\hline
\end{tabular}

Uji heteroskedastisitas bertujuan menguji apakah dalam model regresi terjadi ketidaksamaan varians dari residual satu pengamatan ke pengamatan lain. Pada model regresi yang baik, tidak akan terjadi heteroskedastisitas apabila nilai signifikansinya (p) > 0,05 (Ghozali, 2005). Pada Tabel 5dapat dilihat nilai signifikansi pada variabel rasa komunitas dan komitmen organisasi secara berturut-turut adalah 0,294 dan 0,453 ( $\mathrm{p}>0,05)$. Dapat disimpulkan bahwa tidak terjadi heteroskedastisitas pada model regresi dalam penelitian ini.

Berdasarkan uji normalitas, uji linearitas, uji multikolonieritas, dan uji heteroskedastisitas yang telah dilakukan maka dapat dikatakan data dalam penelitian ini uji asumsi telah dipenuhi sehingga dapat dilanjutkan ke tahap berikutnya yaitu analisis regresi berganda.

\section{Uji Hipotesis}

Hasil uji regresi berganda variabel kecerdasan emosional dan dukungan sosial terhadap penyesuaian diri adalah sebagai berikut:

Tabel 6

Hasil Uji Regresi Berganda Data Penelitian

\begin{tabular}{cccc}
\hline $\mathbf{R}$ & $\mathbf{R}$ Square & Adjusted $\mathbf{R}$ Square & Std. Error of the Estimate \\
\hline 0,854 & 0,729 & 0,723 & 4,666 \\
\hline
\end{tabular}

Pengujian hipotesis mengenai parameter populasi menggunakan informasi dari sampel dan teori probabilitas untuk menentukan apakah hipotesis yang dibuat secara statistik mampu diterima atau ditolak. Hipotesis merupakan suatu jawaban yang bersifat sementara mengenai permasalahan penelitian yang dinyatakan dalam bentuk kalimat pertanyaan (Sugiyono, 2013). Pada penelitian ini, uji hipotesis menggunakan metode analisis regresi berganda dengan bantuan program SPSS 22.0 for Windows. Tabel 6 menunjukkan bahwa nilai $\mathrm{R}$ yang merupakan koefisien regresi sebesar 0,854 dan nilai adjusted $R$ square (R2) yang merupakan nilai koefisien determinasi sebesar 0,723. Artinya rasa komunitas dan komitmen organisasi secara bersama-sama memberikan sumbangan dan menentukan taraf kohesivitas kelompok sebesar $72,3 \%$, sedangkan $27,7 \%$ ditentukan oleh faktor-faktor lain diluar penelitian ini Tabel 7

Hasil Uji Regresi Berganda Signifikansi Nilai F

\begin{tabular}{lccccc}
\hline \multicolumn{7}{c}{ Sum of Squares } & Df & Mean Square & F & Sig. \\
\hline Regression & 5620,359 & 2 & 2810,179 & 129,097 & $.000^{6}$ \\
Residual & 2089,722 & 96 & 21,768 & & \\
\hline Total & $\mathbf{7 7 1 0 , 0 8 1}$ & $\mathbf{9 8}$ & & & \\
\hline
\end{tabular}

a. Dependent Variable: Kohesivitas Kelompok

b. Predictors: (Constant), Rasa Komunitas dan Komitmen Organisasi 
Tabel 7 menunjukkan bahwa nilai $\mathrm{F}$ hitung adalah sebesar 129,097 dengan taraf signifikansi 0,000 $(<0,05)$ sehingga model regresi dapat digunakan untuk memprediksi penyesuaian diri. Berdasarkan hasil yang didapatkan, maka dapat disimpulkan bahwa rasa komunitas dan komitmen organisasi secara bersama-sama berhubungan dengan kohesivitas kelompok.

Tabel 8.

Hasil Uji Regresi Berganda Nilai Koefisien Beta dan Nilai T

\begin{tabular}{cccccc}
\hline \multirow{2}{*}{ Model } & \multicolumn{2}{c}{$\begin{array}{c}\text { Unstandardized } \\
\text { Coefficients }\end{array}$} & $\begin{array}{c}\text { Standardized } \\
\text { Coefficients }\end{array}$ & \multirow{2}{*}{ T } & \multirow{2}{*}{ Sig. } \\
\cline { 2 - 5 } & $\mathbf{B}$ & Std. Error & Beta & & \\
\hline (Constant) & 11,118 & 5,544 & & 2,005 & 0,048 \\
Rasa Komunitas & 0,152 & 0,119 & 0,123 & 1,283 & 0,203 \\
Komitmen Organisasi & 0,670 & 0,086 & 0,748 & 7,786 & 0,000 \\
\hline
\end{tabular}

Berdasarkan tabel 8, didapatkan beberapa hasil yaitu sebagai berikut:

1. Nilai koefisien unstandardized coefficients beta pada variabel komitmen organisasi lebih besar dari nilai koefisien unstandardized coefficient beta pada variabel rasa komunitas $(0,670>0,152)$. Artinya, komitmen organisasi memiliki peran yang lebih besar terhadap kohesivitas kelompok subjek dibandingkan dengan rasa komunitas.

2. Nilai $t$ sebesar 1,283 dan nilai signifikansi sebesar 0,203 ( $\mathrm{p}>0,05$ ) pada variabel rasa komunitas menunjukkan bahwa rasa komunitas tidak memiliki hubungan secara signifikan dengan kohesivitas kelompok.

3. Nilai t sebesar 7,786 dan nilai signifikansi sebesar $0,000(\mathrm{p}<0,05)$ pada variabel komitmen organisasi menunjukkan bahwa komitmen organisasi memiliki hubungan secara signifikan terhadap kohesivitas kelompok.

4. Taraf kohesivitas kelompok dari masing-masing subjek penelitian dapat diprediksi melalui persamaan garis regresi dengan memasukkan nilai Unstandardized Coefficients B seperti berikut ini:

$\mathrm{Y}=11,118+0,152 \mathrm{X} 1+0,670 \mathrm{X} 2$

Keterangan :

$\mathrm{Y}=$ Kohesivitas Kelompok

$\mathrm{X} 1=$ Rasa Komunitas

$\mathrm{X} 2$ = Komitmen Organisasi

Rumus diatas dapat dijelaskan sebagai berikut:

1) Konstanta sebesar 11,118 menyatakan jika tidak ada penambahan atau peningkatan skor pada rasa komunitas maupun komitmen organisasi, maka taraf kohesivitas kelompok yang dihasilkan adalah sebesar 11,118 .
2) Koefisien regresi $X 1$ sebesar 0,152 dan bertanda positif menunjukkan rasa komunitas memiliki hubunga yang searah dengan kohesivitas kelompok. Hal ini mengandung arti setiap penambahan atau peningkatan satuan skor subjek pada variabel rasa komunitas, maka akan terjadi kenaikan taraf koheivitas kelompok sebesar 0,152.

3) Koefisien regresi $X 2$ sebesar 0,670 dan bertanda positif menunjukkan bahwa komitmen organisasi mempunyai hubungan yang searah dengan kohesivitas kelompok. Hal ini berarti setiap penambahan atau peningkatan satuan skor subjek pada variabel komitmen organisasi, maka akan terjadi kenaikan taraf kohesivitas kelompok sebesar 0,670 .

Berdasarkan hasil uji regresi berganda yang telah didapatkan, maka rangkuman hipotesis mayor dan minor penelitian ini dapat dilihat pada tabel 9 . Tabel 9.

Rangkuman Hasil Uji Hipotesis Penelitian

\begin{tabular}{|c|c|c|}
\hline No & Hipotesis & Hasil \\
\hline 1 & $\begin{array}{l}\text { Hipotesis Mayor: } \\
\text { Rasa komunitas dan komitmen organisasi secara bersama- } \\
\text { sama berhubungan dengan kohesivitas kelompok pada } \\
\text { anggota Sekaa Teruna-Teruni di Badung }\end{array}$ & $\begin{array}{l}\text { Hipotesis Alternatif } \\
\text { Diterima }\end{array}$ \\
\hline 2 & $\begin{array}{l}\text { Hipotesis Minor: } \\
\text { a. Rasa komunitas tidak berhubungan langsung dengan } \\
\text { kohesivitas kelompok pada anggota Sekaa Teruna- } \\
\text { Teruni di Badung }\end{array}$ & Hipotesis Nol Diterima \\
\hline & $\begin{array}{l}\text { b. Komitmen organisasi berhubungan langsung dengan } \\
\text { dengan kohesivitas kelompok pada anggota Sekaa } \\
\text { Teruna-Teruni di Badung }\end{array}$ & $\begin{array}{l}\text { Hipotesis Alternatif } \\
\text { Diterima }\end{array}$ \\
\hline
\end{tabular}

\section{Analisis Gender}

Analisis tambahan dilakukan peneliti untuk Tujuan analisis gender dalam penelitian ini adalah untuk memperkaya hasil penelitian. Analisis terhadap gender dilakukan untuk mengetahui apakah terdapat perbedaan taraf kohesivitas kelompok, rasa komunitas dan komitmen organisasi apabila dikategorikan berdasarkan jenis kelamin subjek yang dibagi menjadi dua, yaitu laki-laki dan perempuan. Analisis tambahan ini diuji dengan menggunakan independent sample $\mathrm{t}$-test dengan bantuan program SPSS 22.0 for Windows.

Analisis tambahan tidak dapat dilakukan dengan menggunakan karakteristik subjek selain jenis kelamin, karena karakteristik subjek seperti usia, pendidikan, banjar, dan lama bergabung tidak memenuhi syarat untuk dilakukan uji komparasi dengan menggunakan independent sample t-test maupun dengan uji anova (untuk karakteristik subjek yang lebih dari dua kategori). Hal ini disebabkan karena jumlah sampel yang akan dibandingkan pada masing-masing karakteristik subjek tidak berada dalam satu kategori yang sama. Uji komparasi hanya dapat dilakukan apabila dua atau lebih sampel yang akan dibandingkan sama-sama dikategorikan sebagai sampel yang berukuran kecil $(\mathrm{N}<30)$ atau sama-sama merupakan sampel yang berukuran besar (N>30) (Sudijono, 2012). 


\section{HUBUNGAN ANTARA RASA KOMUNITAS DAN KOMITMEN ORGANISASI DENGAN KOHESIVITAS KELOMPOK}

Berdasarkan uji independent sample t-test, dinyatakan terdapat perbedaaan taraf kohesivitas kelomok, rasa komunitas dan komitmen organisasi berdasarkan jenis kelamin apabila nilai signifikansi (p) pada tabel $\mathrm{t}<0,05$. Rangkuman hasil uji independent sample t-test pada masing-masing variabel dapat dilihat tabel

10.

Tabel 10.

Hasil Uji Independent Sample t-Test

\begin{tabular}{lccccc}
\hline & \multicolumn{2}{c}{$\begin{array}{c}\text { Levene's Test for Equality } \\
\text { of Variances }\end{array}$} & \multicolumn{3}{c}{ t-test for } \\
\cline { 2 - 6 } & F & Siguality & of Means \\
\hline Kohesivitas Kelompok & & T & Df & $\begin{array}{c}\text { Sig. } \\
\text { (2-tailed) }\end{array}$ \\
Rasa Komunitas & .581 & .448 & -.174 & 97 & .861 \\
Komitmen Organisasi & .013 & .910 & -.361 & 97 & .719 \\
\hline
\end{tabular}

Berdasarkan tabel 10, dapat dilihat nilai signifikansi pada tabel Levene's test for equality of variances variabel kohesivitas kelompok adalah 0,448 ( $\mathrm{p}>0,05$ ) yang berarti data kohesivitas kelompok subjek penelitian bersifat homogen, sehingga memenuhi syarat untuk dilakukan uji t-test independen. Nilai signifikansi variabel kohesivitas kelompok pada kolom t-test for equality of means adalah 0,861 ( $p$ > $0,05)$, yang berarti tidak terdapat perbedaan taraf kohesivitas kelompok antara subjek yang berjenis kelamin laki-laki dan perempuan.

Berdasarkan tabel 10, dapat dilihat nilai signifikansi pada tabel Levene's test for equality of variances variabel rasa komunitas adalah $0,910(\mathrm{p}>0,05)$ yang berarti data rasa komunitas subjek penelitian bersifat homogen, sehingga memenuhi syarat untuk dilakukan uji t-test independen. Nilai signifikansi variabel rasa komunitas pada kolom t-test for equality of means adalah 0,719 ( $p>0,05)$, yang berarti tidak terdapat perbedaan taraf rasa komunitas antara subjek yang berjenis kelamin laki-laki dan perempuan.

Berdasarkan tabel 10, dapat dilihat nilai signifikansi pada tabel Levene's test for equality of variances variabel komitmen organiasi adalah 0,241 ( $\mathrm{p}>0,05$ ) yang berarti data komitmen organisasi subjek penelitian bersifat homogen, sehingga memenuhi syarat untuk dilakukan uji t-test independen. Nilai signifikansi variabel komitmen organisasi pada kolom t-test for equality of means adalah 0,622 ( $\mathrm{p}>$ $0,05)$, yang berarti tidak terdapat perbedaan taraf komitmen organisasi antara subjek yang berjenis kelamin laki-laki dan perempuan.

\section{PEMBAHASAN DAN KESIMPULAN}

Berdasarkan hasil penelitian yang telah didapatkan dan dianalisis dengan menggunakan teknik regresi berganda, dapat diketahui bahwa hipotesis mayor penelitian ini yaitu rasa komunitas dan komitmen organisasi berhubungan secara bersama-sama dengan kohesivitas kelompok pada anggota Sekaa Teruna-Teruni dapat diterima. Hal ini dapat dilihat dari koefisien $\mathrm{R}$ pada hasil uji regresi adalah sebesar 0,854 (tabel
26), dan nilai signifikansi uji $\mathrm{F}$ adalah 0,000 (tabel 27) yang menunjukkan bahwa rasa komunitas dan komitmen organisasi berhubungan secara bersama-sama dengan kohesivitas kelompok. Koefisien determinasi sebesar 0,723 menunjukkan bahwa kedua variabel bebas yaitu rasa komunitas dan komitmen organisasi memiliki sumbangan efektif sebesar $72,9 \%$ (tabel 26) terhadap variabel tergantung yaitu kohesivitas kelompok. Berdasarkan hasil yang didapatkan, dapat ditarik kesimpulan bahwa rasa komunitas dan komitmen organisasi menentukan $72,3 \%$ taraf kohesivitas kelompok yang dimiliki anggota Sekaa Teruna-Teruni di Badung. Sebesar $27,7 \%$ lainnya dipengaruhi oleh faktor lain yang tidak dimasukkan dalam penelitian ini.

Menurut McMillan dan Chavis (1986), rasa komunitas anggota Sekaa Teruna-Teruni terbentuk dari perasaan-perasaan yang dimiliki anggota Sekaa Teruna-Teruni seperti perasaan yang nyaman, senang berbagi cerita karena kesamaan dimiliki anggota Sekaa Teruna-Teruni dengan anggota lain dan ikatan yang kuat dari interaksi yang mereka lakukan. Semakin banyaknya interaksi yang dilakukan oleh anggota Sekaa Teruna-Teruni, akan menjalin keakraban dan kepaduan di antara anggota Sekaa Teruna-Teruni.

Robin dan Judge (2008) menyebutkan bahwa komitmen organisasi dibagi menjadi tiga aspek yaitu komitmen afektif, komitmen berkelanjutan dan komitmen normatif. Anggota organisasi yang berkomitmen dengan organisasinya berdasarkan aspek afektif, melakukan pekerjaannya karena memang menginginkan dan tetap bertahan dalam organisasi karena mereka memandang hubungan personal yang terjalin dengan organisasi sejalan dengan tujuan dan nilai-nilai anggota organisasi. Hubungan antar anggota Sekaa Teruna-Teruni yang terikat oleh hubungan emosional dan interaksi antar kelompok sesuai dengan pernyataan dari Paxtoon dan Moody (dalam Taylor dkk, 2009) yaitu apabila anggota kelompok saling menyukai satu sama lain, dan terikat oleh hubungan pertemanan, kepaduan akan tinggi.

\section{Hipotesis Minor I : Rasa Komunitas tidak Mempunyai Hubungan Langsung dengan Kohesivitas Kelompok pada Anggota Sekaa Teruna-Teruni di Badung.}

Berdasarkan hasil penelitian yang didapatkan, rasa komunitas tidak mempunyai hubungan langsung dengan kohesivitas kelompok pada anggota Sekaa Teruna-Teruni. Rasa komunitas bukan satu-satunya faktor yang mempengaruhi kohesivitas kelompok. Banyak faktor-faktor diluar penelitian yang dapat mempengaruhi kohesivitas kelompok. Robbins (dalam Munandar, 2001) menyebutkan faktor-faktor yang ikut menentukan derajat kelekatan kelompok ialah: pertama yaitu lamanya waktu bersama Sekaa Teruna-Teruni yang mana makin lama berada bersama Sekaa 
Teruna-Teruni, makin saling mengenal, makin dapat timbul sikap toleran terhadap yang lain. Kedua yaitu parahnya masa awal yang mana semakin sulit calon anggota memasuki Sekaa Teruna-Teruni, maksudnya yaitu makin sulit anggota diterima di dalam Sekaa Teruna-Teruni sebagi anggota, makin lekat Sekaa Teruna-Teruninya. Pada awal masuk, biasanya para anggota kelompok yang lama menguji anggota baru, dengan cara-cara yang khas oleh kelompoknya. Ketiga yaitu besarnya kelompok; makin besar Sekaa Teruna-Teruninya makin sulit terjadi interaksi yang intensif antar para anggotanya, makin kurang lekat Sekaa Teruna-Teruninya. Keempat yaitu ancaman dari luar yang mana kelekatan kelompok akan bertambah jika kelompok mendapat ancaman dari luar. Kelima yaitu keberhasilan di masa lalu.

Selain faktor dari kohesivitas kelompok, faktor dari subjek juga dapat mempengaruhi hasil dari penelitian ini. Pada saat penelitian bisa saja terdapat yang menjawab dengan asalasalan dan juga terdapat subjek yang menyalin kuisioner dari temannya. Menurut Azwar (2015), terdapat faktor-faktor yang dapat melemahkan validitas dalam penelitian. Faktor-faktor tersebut antara lain, penampilan skala dimana subjek saat penelitian terdengar mengeluh karena jumlah aitem yang cukup banyak. Kedua yaitu situasi ruang yang menunjuk pada kondisi di dalam tempat pelaksanaan penyajian atau administrasi. Tempat penelitian yang dilakukan di lingkungan banjar membuat beberapa anggota kurang dapat berkonsentrasi dalam menjawab kuisioner. Ketiga yaitu kondisi subjek, terdapat beberapa subjek yang menjawab kuisioner saat pulang sekolah dan pulang kerja dimana kondisi subjek kemungkinan sedang lelah.

Hipotesis Minor II : Komitmen Organisasi Berhubungan Langsung dengan Kohesivitas Kelompok pada Anggota Sekaa Teruna-Teruni.

Berdasarkan hasil penelitian yang didapatkan, komitmen organisasi merupakan faktor lain yangberhubungan dengan kohesivitas kelompok pada anggota Sekaa TerunaTeruni. Hasil penelitian ini sejalan dengan pengertian kohesivitas menurut Taylor dkk (2009) yaitu kohesivitas adalah karakteristik kelompok secara keseluruhan, berdasarkan komitmen individu kepada kelompok. Hasil penelitian ini sejalan dengan hasil penelitian oleh Purwaningtyastuti dkk (2012) yang menyatakan bahwa ada hubungan antara komitmen terhadap organisasi dengan kohesivitas kelompok.

Kohesivitas dalam kelompok merupakan gejala yang kompleks yang disebabkan oleh kombinasi daya tarik atau daya tolak terhadap masing-masing anggota. Hal tersebut sesuai dengan faktor kohesivitas kelompok dari Forsyth (2010) yang menyatakan bahwa faktor daya tarik dari kohesivitas kelompok merupakan pengaruh saling menyukai dan formasi kelompok yang juga mempengaruhi kohesivitas dalam kelompok yang terbentuk. Hal tersebut juga sesuai dengan pengertian kohesivitas menurut Robbins dan Judge (2008) bahwa kohesivitas merupakan tingkat di mana para anggota kelompok saling tertarik satu sama lain dan termotivasi untuk tinggal di dalam kelompok tersebut (Robbins \& Judge, 2008).

Anggota Sekaa Teruna-Teruni dengan komitmen organisasi yang tinggi akan memiliki loyalitas tinggi terhadap Sekaa Teruna-Teruni. Anggota Sekaa Teruna-Teruni dengan loyalitas tinggi bersedia berkorban demi kepentingan organisasi. Contohnya dalam kehidupan sehari-hari di dalam organisasi adalah dengan bersikap sebagai anggota Sekaa Teruna-Teruni yang baik (Teresia \& Suyasa, 2008).

Kepercayaan dan penerimaan yang penuh atas nilainilai dan tujuan organisasi, keinginan untuk berusaha sekuat tenaga demi kepentingan organisasi dan keinginan untuk mempertahankan diri agar tetap menjadi anggota Sekaa Teruna-Teruni (Tanzaq, 2007). Hal yang sama juga disebutkan dalam hasil penelitian dari Rimata (2014) bahwa anggota yang mempunyai komitmen yang tinggi terhadap organisasi, akan memberikan usaha yang maksimal untuk tercapainya tujuan organisasi, bersedia berkorban demi organisasi dan mempunyai keinginan yang kuat untuk tetap tinggal dalam organisasi Sekaa Teruna-Teruni. Keinginan untuk mempertahankan diri agar menjadi anggota anggota Sekaa Teruna-Teruni yang membuat kohesivitas kelompok pada anggota Sekaa Teruna-Teruni juga tinggi.

Hasil penelitian dari Dwityanto dan Amalia (2012) menyatakan bahwa ada hubungan yang positif dan signifikan antara kohesivitas kelompok dengan komitmen organisasi pada karyawan. Karakter yang ditunjukkan oleh individu yang memiliki komitmen tinggi terhadap organisasi sangat bersesuaian dengan karakter yang dimiliki kelompok dengan kohesivitas tinggi. Pada anggota Sekaa Teruna-Teruni yang kohesivitasnya tinggi akan memiliki tingkat ketertarikan pada anggota dan kelompok yang kuat. Kemudian tingkat kohesivitas akan memiliki pengaruh terhadap komitmen organisasi tergantung dari seberapa jauh kesamaan tujuan kelompok dengan organisasi.

Hasil penelitian Dwityanto dan Amalia (2012) sejalan dengan hasil penelitian dari Trihapsori dan Nashori (2011) yang menyatakan bahwa ada hubungan positif yang sangat signifikan antara kohesivitas kelompok dengan komitmen orgnisasi. Robbins (dalam Trihapsori \& Nashori 2011) menyatakan bahwa angota Sekaa Teruna-Teruni yang memiliki kohesivitas kelompok yang tinggi terhadap Sekaa Teruna-Teruninya akan mempunyai keinginan yang rendah untuk keluar dari organisasi Sekaa Teruna-Teruni dimana anggota tersebut berada.

Anggota Sekaa Teruna-Teruni yang memiliki komitmen terhadap Sekaa Teruna-Teruni akan memunculkan 


\section{HUBUNGAN ANTARA RASA KOMUNITAS DAN KOMITMEN ORGANISASI DENGAN KOHESIVITAS KELOMPOK}

rasa memiliki (sense of belonging) pada diri anggota tersebut. Hal ini sesuai dengan aspek kohesivitas kelompok yang dikemukakan oleh Forsyth (2010) bahwa dalam aspek kohesivitas rasa mengandung pengertian koherensi yang dibentuk kelompok, rasa memiliki kelompok dan persatuan anggota kelompok.

Pramadani dan Fajrianthi (2012) menyebutkan bahwa anggota yang memiliki komitmen normatif akan melaksanakan semua tugas dan kewajiban yang diberikan oleh organisasi Sekaa Teruna-Teruni. Hal ini sesuai dengan aspek kohesivitas kelompok yang dikemukakan oleh Forsyth (2010) bahwa dalam kohesivitas tugas menjelaskan kekuatan dari kelompok yang fokus dari tugas, dan tingkat kerjasama yang ditampilkan. Komitmen organisasi merupakan kekuatan keterlibatan dan kesetian kepada organisasi Sekaa TerunaTeruni (Verawati \& Utomo, 2012). Hal ini sejalan dengan pengertian kohesivitas dari Taylor dkk, 2009 yaitu kohesivitas didefinisikan sebagai kekuatan, baik positif maupun negatif, yang menyebabkan anggota tetap dalam kelompok.

\section{Deskripsi Statistik dan Kategorisasi Data Variabel Kohesivitas Kelompok}

Berdasarkan hasil deskripsi statistik dan kategorisasi data variabel penelitian, dapat diketahui bahwa mayoritas taraf kohesivitas kelompok pada anggota Sekaa Teruna-Teruni tergolong tinggi, yaitu sebanyak 47 orang (47,5\%) (tabel 19). Hal ini mencerminkan bahwa anggota Sekaa Teruna-Teruni sudah memiliki kohesivitas kelompok terhadap Sekaa Teruna Teruninya. Kohesivitas kelompok yang tinggi ditandai dengan anggota saling menyukai satu sama lain, dan terikat oleh hubungan pertemanan yang mengakibatkan kepaduan atau kohesivitas yang tinggi (Paxton \& Moody dalam Taylor, dkk 2009).

Selain itu kohesivitas kelompok yang tinggi juga ditandai dengan tiap anggota Sekaa Teruna-Teruni saling berinterasi antar satu sama lain, memperoleh tujuan mereka, saling membantu tiap pertemuan dan apabila anggota Sekaa Teruna-Teruni tidak kompak, maka tiap anggota Sekaa Teruna-Teruni akan saling tidak menyukai satu sama lain dan akan menimbulkan perbedaan pendapat (Greeberg, 2005). Munandar (2001) juga menyatakan bahwa semakin para anggota saling tertarik dan makin sepakat anggota terhadap sasaran dan tujuan kelompok maka makin kohesif Sekaa Teruna-Teruninya.

Forsyth (dalam Hutama, 2015) menyebutkan bahwa kelompok yang kohesif memiliki ciri- ciri seperti: masing masing anggota timbul keterdekatan, sehingga bisa mempengaruhi satu sama lain, rasa toleransi, saling membagi, saling mendukung terutama dalam menghadapai masalah, keeratan hubungan, saling tergantung untuk tetap tinggal dalam kelompok. Hariadi (dalam Purwaningtyastuti dkk,
2012) menyebutkan semakin kuat kohesi anggota berpengaruh meningkatkan keberhasilan kelompok sebagai unit belajar. Semakin kuat kohesi menunjukkan sema kin tingginya ketertarikan di antara anggota kelompok. Hal ini mempermudah dan mendorong anggota satu dengan yang lainnya saling belajar dan tukar informasi atau pendapat tentang materi penyuluhan sehingga semakin tinggi tingkat keberhasilan kelompok sebagai unit belajar.

Hasil penelitian dari Darwita (2012) menyebutkan bahwa semakin tinggi kohesivitas kelompok pada siswa maka akan semakin tinggi pula tanggung jawab pada siswa. Dengan kata lain pada anggota Sekaa Teruna-Teruni yang memiliki tingkat kohesivitas kelompok tinggi maka anggota Sekaa Teruna-Teruni akan memililiki daya tarik yang tinggi terhadap Sekaa Teruna-Teruni, tanggung jawab yang tinggi terhadap Sekaa Teruna-Teruni serta dapat meningkatkan keberhasilan dari tujuan yang ditetapkan oleh Sekaa Teruna-Teruni.

Adanya kohesivitas kelompok yang tinggi dapat memberikan motivasi dan semangat kerja yang tinggi kepada karyawan, dimana sesama karyawan akan saling membantu, sehingga dapat meningkatkan produktivitas kinerjanya (Kurniawati, 2016). Pada anggota Sekaa Teruna-Teruni yang memiliki kohesivitas tinggi maka anggota-anggota tersebut memiliki semangat yang tinggi untuk saling membantu satu sama lain sehingga tugas -tugas dalam Sekaa Teruna-Teruni akan cepat selesai.

Taylor dkk (2009) menyebutkan bahwa segala sesuatu yang meningkatkan kepuasan dan semangat cenderung akan memperkuat kepaduan. Anggota Sekaa Teruna-Teruni yang memiliki kepuasan dan semangat yang tinggi terhadap Sekaa Teruna-Teruni maka kepaduan atau kohesivitas anggota Sekaa Teruna-Teruni akan cenderung lebih kuat atau tinggi. Anggota kelompok yang yang sangat kohesif cenderung dipengaruhi oleh kelompok itu dan mau menyesuaikan diri dengan norma kelompok (McGrath, dalam Taylor dkk 2009).

Remaja yang memiliki waktu luang yang banyak, dihabiskan dengan ngobrol dan nongkrong dengan teman sebagai dari jenis kelamin yang berbeda (Larson \& Verma dalam Papalia dkk, 2008). Sehingga dalam berorganisasi di Sekaa Teruna-Teruni dengan waktu luang yang dimiliki remaja dapat meningkatkan kohesivitas kelompok antar anggota yang merupakan teman sebaya mereka. Remaja dalam kaitanya dengan hubungan pertemanan, remaja cenderung memilih teman yang mirip dengan diri mereka, dan teman saling memengaruhi untuk menjadi semakin mirip (Papalia dkk, 2008), sehingga peran teman sebaya juga memengaruhi kohesivitas kelompok remaja dalam mengikuti kegiatan Sekaa Teruna-Teruni. 
Deskripsi Statistik dan Kategorisasi Data Variabel Rasa Komunitas.

Berdasarkan hasil deskripsi statistik dan kategorisasi data variabel penelitian, dapat diketahui bahwa mayoritas taraf rasa komunitas pada anggota Sekaa Teruna-Teruni tergolong tinggi dan sangat tinggi, yaitu masing-masing kategori sebanyak 48 orang $(48,5 \%)$ (tabel 20). Hal ini mencerminkan bahwa anggota Sekaa Teruna-Teruni sudah memiliki rasa komunitas terhadap Sekaa Teruna-Teruninya. Hal ini sejalan dengan hasil penelitian dari Prayoga dan Herdiyanto (2013) juga menyebutkan bahwa perassan memiliki pengurus subak akan kebersamaan demi mencapai komitmennya pada subak di Kecamatan Pekutatan lebih didominasi oleh rasa komunitas pengurus subak kategori sangat tinggi.

Hasil penelitian dari Prayoga dan Herdiyanto (2013) menyatakan bahwa bahwa tingginya rasa komunitas pada pengurus subak menunjukkan bahwa pengurus subak dengan rasa komunitas akan membentuk kelekatan kepada komunitasnya dan memberikan pengaruh yang berarti dalam organisasi. Bentuk pengaruh berarti itu berupa: proses mengelola organisasi, membangun hubungan dengan kelompok di luar organisasi, memberi pengaruh terhadap persepsi individu dalam keikutsertaan dalam organisasi serta bisa mempengaruhi masyarakat luas dan membentuk hubungan dengan orang-orang yang tidak mengenal satu sama lain dalam meningkatkan kualitas hidup.

Hasil penelitian dari Prayoga dan Herdiyanto (2013) juga menyebutkan bahwa perasaan memiliki pengurus subak akan kebersamaan demi mencapai komitmennya pada subak di Kecamatan Pekutatan lebih didominasi oleh rasa komunitas pengurus subak kategori sangat tinggi. Rasa komunitas yang dimiliki anggota akan membentuk para anggota komunitas menjadi ingin lebih mempertahankan kelekatan kelompoknya (McMillan \& Chavis, 1996). Pengertian tersebut berarti bahwa Sekaa Teruna-Teruni yang memiliki tingkat rasa komunitas yang tinggi dan sangat tinggi ingin lebih mempertahankan kelekatan dalam Sekaa Teruna-Teruni mereka.

McMillan dan Chavis (1996) mengungkapkan bahwa rasa komunitas sebagai jiwa dalam memiliki kebersamaan, perasaan bahwa terdapat sturktur otoritas yang dapat dipercaya, kesadaran akan tugas atau pekerjaan, kebersamaan yang saling menguntungkan dan jiwa yang berasal dari pengalaman bersama yang diawetkan sebagai seni.

\section{Deskripsi Statistik dan Kategorisasi Data Variabel Komitmen Organisasi}

Berdasarkan hasil deskripsi statistik dan kategorisasi data variabel penelitian, dapat diketahui bahwa mayoritas taraf komitmen organisasi pada anggota Sekaa Teruna-Teruni tergolong tinggi, yaitu sebanyak 48 orang (48,5\%) (tabel 21). Hal ini mencerminkan bahwa anggota Sekaa Teruna-Teruni sudah memiliki komitmen organisasi terhadap Sekaa Teruna Teruninya.

Hasil dari penelitian Teresia dan Suyasa (2008) menyatakan semakin tinggi komitmen organisasi karyawan, maka semakin tinggi pula perilaku OCB sehingga semakin karyawan berkomitmen terhadap organisasi, semakin karyawan ingin bersikap melebihi tuntutan tugas apabila dibutuhkan. Tingginya komitmen organisasi dipengaruhi oleh faktor pribadi anggota dan faktor organisasi. Terdapat tiga faktor organisasi yang memengaruhi komitmen organisasi. Pertama, karakteristik kerja yang berkaitan dengan peran anggota dalam organisasi. Komitmen organisasi cenderung lebih tinggi pada anggota dengan kejelasan peran (Luthans, 2002). Ketidakjelasan peran yang diberikan oleh organisasi kepada anggotanya akan mengakibatkan timbulnya konflik peran, yang pada akhirnya akan mempengaruhi komitmen karyawan (Cherrington dalam Teresia \& Suyasa, 2008). Kedua, karakteristik struktur yang dipengaruhi oleh besarnya organisasi, bentuk organisasi. Ketiga, pengalaman kerja yang dimiliki oleh anggota. Komitmen organisasi cenderung lebih tinggi pada anggota yang memiliki pengalaman kerja menyenangkan, seperti sikap positif dari rekan anggota, merasa organisasi dapat memenuhi keinginannya, dan merasa dirinya penting bagi organisasi (Cherrington dalam Teresia \& Suyasa, 2008).

Meyer dan Allen (1990) menyebutkan tingkat komitmen organisasi terkait dengan sejauh mana seseorang anggota mengalami rasa kesatuan dengan organisasi mereka. Hogged dan Anthony (dalam Tanzaq, 2007 ) menyatakan bahwa komitmen organisasi yang tinggi disebabkan oleh anggota organisasi yang puas terhadap tugas dan lingkungan serta yang terlibat dengan aktivitas organisasi. Anggota yang memiliki komitmen terhadap organisasinya akan tetap tinggal dalam organisasi, bekerja secara rutin dan fullday, melindungi aset-aset organisasi, dan mempercayai tujuan organisasi yang akan diraih (Mayer \& Allen dalam Pramadani dan Fajrianthi, 2012).

Tingkatan komitmen organisasi yang tinggi dikarakteristikkan oleh penerimaan yang kuat kepada nilainilai organisasi dan kesediaan untuk memperluas usaha agar tetap berada dalam kelompok (Reichers, dalam Kusumaputri 2015). Kehendak untuk tetap bertahan dalam organisasi menjelaskan bahwa kecenderungan perilaku pada tingkat komitmen organisasi yang tinggi sangat terkait dengan dimensi komitmen afektif, yaitu individu bertahan karena memang mereka menginginkannya (Kusumaputri, 2015).

Faktor-faktor yang dapat mempengaruhi tingginya komitmen organisasi yaitu faktor-faktor yang meliputi pekerjaan, kesempatan pada anggota, karakteristik pribadi, 


\section{HUBUNGAN ANTARA RASA KOMUNITAS DAN KOMITMEN ORGANISASI DENGAN KOHESIVITAS KELOMPOK}

hubungan positif, struktur organisasi serta gaya manajemen (Kusumaputri, 2015). Kusumputri (2015) juga menyebutkan bahwa komitmen organisasi yang tinggi merupakan hasil dari semakin tingginya tanggung jawab, kemadirian dalam pekerjaan, semakin sedikit jenis pekerjaan yang monoton, berulang-ulang dan semakin menariknya pekerjaan tersebut. Mayer dan Allen (dalam Kusumaputri, 2015) menyebutkan yaitu semakin tua anggota organisasi dengan senioritas, cenderung semakin memiliki tingkat komitmen organisasi yang tinggi. Hubungan organisasi yang merefleksikan saling menghargai antar anggota dapat menumbuhkan komitmen pada diri mereka sendiri terhadap organisasi.

\section{Analisis Gender}

Berdasarkan hasil analisis dengan menggunakan uji independent sample t-test pada variabel kohesivitas kelompok diperoleh hasil bahwa tidak terdapat perbedaan kohesivitas kelompok berdasarkan antara laki-laki dan perempuan. Hasil ini didukung dengan temuan penelitian dari Utami dan Purwaningtyastuti (2012) yaitu tidak tidak terdapat perbedaan kohesivitas karyawan ditinjau dari gender yang dibagi dalam kategori laki-laki dan perempuan. Penelitian tersebut menekankan pada gender dikarenakan dalam gender tidak hanya ada pembagian biologis tapi sudah mengarah pada tugas-tugas dalam hubungan sosial.

Perempuan cenderung agak lebih terbuka dibandingkan laki-laki, terutama pada aspek sifat yang berkaitan dengan hubungan interpersonal dan pertemanan (Costa, Terracciano, \& McCrae dalam Forsyth, 2010). Lakilaki dan perempuan cenderung memberlakukan peran yang berbeda dalam budaya, peran dapat membentuk peluang bagi keterlibatan dalam kelompok (Forsyth, 2010).

Analisis tambahan dengan menggunakan uji independent sample t-test pada variabel rasa komunitas menunjukkan tidak terdapat perbedaan rasa komunitas berdasarkan jenis kelamin. Hasil penelitian ini sejalan dengan hasil penelitian dari Wighting (2011) yang menyatakan bahwa tidak ada perbedaan jenis kelamin yang signifikan baik dalam rasa komunitas atau perceived learning. Dalam bermasyarakat, wanita dapat diberikan peran yang mempromosikan fasilitasi rasa komunitas sehingga bermanfaat bagi lingkungan belajar untuk kedua jenis kelamin dalam program lisensi alternatif (Wighting, 2011).

Analisis tambahan dengan menggunakan uji independent sample t-test pada variabel komitmen organisasi menunjukkan tidak terdapat perbedaan komitmen organisasi berdasarkan jenis kelamin. Hasil penelitian ini sejalan dengan hasil penelitian dari Mulyono (2016) yang menyatakan bahwa tidak ada perbedaan komitmen organisasi para anggota lembaga Kemahasiswaan Universitas (LKU) di Universitas Kristen Satya Wacana ditinjau dari jenis kelamin. Penelitian dari Mulyono (2016) jga menyebutkan bahwa ada beberapa kemungkinan komitmen organisasi di antara laki-laki dan perempuan menunjukkan tidak berbeda. Cogalty (dalam Mulyono, 2016) menyebutkan bahwa komitmen organisasi sangat penting bagi laki-laki dan perempuan karena dengan adanya komitmen organiasi dapat menumbuhkan kekuatan yang besar pada setiap tugas yang dijalankan baik itu laki-laki maupun perempuan.

Keterbatasan penelitian ini adalah keterbatasan dalam jurnal penelitian di Indonesia terkait dengan variabel rasa komunitas, tidak semua anggota pada Sekaa Teruna-Teruni yang terpilih ikut terlibat terlibat dalam penelitian ini, dikarenakan usia mereka tidak memenuhi karakteristik penelitian dan ketidakhadiran mereka saat penelitian berlangsung. Keterbatasan lainnya yaitu, Ketua Sekaa TerunaTeruni sudah mengumpulkan anggota-anggotanya di banjar namun tetap ada saja anggota yang berhalangan hadir sehingga tidak bisa memperoleh jumlah sampel yang cukup banyak setiap Sekaa Teruna-Teruni. Selain itu ketika peneliti mencari anggota ke rumah-rumah, anggota Sekaa TerunaTeruni tidak semua di rumah dikarenakan masih ada kegiatan sekolah dan bekerja, oleh sebab itu peneliti harus mencari anggota-anggota tersebut ketika hari menjelang malam. Keterbatasan lainnya yaitu susahnya menghubungi kelian dinas untuk memperoleh ijin penelitian sehingga peneliti harus mencari kelian dinas ketika yang bersangkutan ada di rumah atau di kantor desa. Keterbatasan lain dalam penelitian ini adalah penelitian ini hanya memberikan data deskriptif mengenai lamanya anggota bergabung di Sekaa TerunaTeruni, tingkat pendidikan terkahir dan hanya memberikan data deskriptif mengenai rentang usia dan asal banjar subjek. Penelitian ini belum memberikan data mengenai perbedaan kohesivitas kelompok, rasa komunitas dan komitmen organisasi apabila dikategorikan berdasarkan usia, pendidikan terkahir, banjar, dan lama subjek bergabung di Sekaa TerunaTeruni.

Setelah melakukan prosedur analisis data penelitian, karya ini telah mencapai tujuan penelitian yaitu mengetahui hubungan antara rasa komunitas dan komitmen organisasi dengan kohesivitas kelompok pada anggota Sekaa TerunaTeruni di Badung. Berdasarkan penelitian yang telah dilakukan, dapat ditarik kesimpulan bahwa secara bersamasama rasa komunitas dan komitmen organisasi mempunyai hubungan yang signifikan dengan kohesivitas kelompok pada anggota Sekaa Teruna-Teruni di Badung. Rasa komunitas mempunyai hubungan dengan kohesivitas kelompok pada anggota Sekaa Teruna-Teruni di Badung, namun hubungan tersebut bukan hubungan yang sifatnya fungsional. Komitmen organisasi berhubungan langsung dengan dengan kohesivitas kelompok pada anggota Sekaa Teruna-Teruni di Badung dan hubungan tersebut merupakan hubungan yang sifatnya fungsional.Taraf kohesivitas kelompok dan komitmen organisasi yang dimiliki oleh anggota Sekaa Teruna-Teruni di Badung mayoritas tergolong tinggi, dan taraf rasa komunitas 
tergolong tinggi dn sangat tinggi. Tidak ada perbedaan taraf kohesivitas kelompok, rasa komunitas, dan komitmen organisasi antara anggota Sekaa Teruna-Teruni di Badung yang berjenis kelamin laki-laki dan anggota Sekaa TerunaTeruni yang berjenis kelamin perempuan.

Berdasarkan kesimpulan yang telah dipaparkan, maka peneliti memberikan saran kepada remaja yaitu sebaiknya mencari informasi dan bergabung dalam kelompok -kelompok yang dapat mengasah kemampuan, bakat dan softskill yang dimiliki. Informasi yang dicari dapat melalui teman-teman yang bergabung dalam organisasi atau media yang mempublikasikan kegiatan dalam organisasi khususnya Sekaa Teruna-Teruni. Remaja sebaiknya terlibat dalam kegiatan-kegiatan yang positif dalam Sekaa Teruna-Teruni sehingga diharapkan dapat mempertahankan keaktifan remaja dalam Sekaa Teruna-Teruni sehingga kohesivitas kelompok yang diikutinya dapat terjaga. Serta Remaja yang bergabung dalam Sekaa Teruna-Teruni sebaiknya mengetahui setiap permasalahan yang dialami oleh Sekaa Terun Teruni yang dinaunginya sehingga dapat ikut mencari solusi untuk menyelesaikan permasalahan di Sekaa Teruna-Teruni. Hal ini mencerminkan bahwa diharapkan remaja yang menjadi anggota tetap menjaga rasa komunitas yang sangat tinggi di Sekaa Teruna-Teruni. Remaja yang belum masuk keanggotaan Sekaa Teruna-Teruni diharapkan dapat mempelajari tentang kegiatan dan permasalahan yang terdapat di Sekaa TerunaTeruni sehingga dapat menjadi cerminan saat bergabung dalam Sekaa Teruna-Teruni

Saran bagi Anggota Sekaa Teruna-Teruni sebaiknya tetap mengikuti kegiatan yang dilaksanakan oleh Sekaa Teruna-Teruni, tetap menghormati peraturan-peraturan yang berlaku dalam Sekaa Teruna-Teruninya. Sehingga kohesivitas kelompok pada Sekaa Teruna-Teruninya dapat terjaga dan Sekaa Teruna-Teruni yang merupakan budaya Bali dapat tetap berkembang. Anggota Sekaa Teruna-Teruni diharapkan selalu menanamkan rasa memiliki terhadap Sekaa Teruna-Teruni agar tetap terjaga komitmen dalam Sekaa Teruna-Teruni. Rasa memiliki tersebut dapat diwujudkan dengan tetap mengetahui informasi di Sekaa Teruna-Teruni yang dinaunginya. Anggota Sekaa Teruna-Teruni diharapkan bersama-sama dapat menyusun program yang dapat menarik minat seluruh anggota untuk hadir dalam kegiatan.

Orangtua diharapkan untuk tetap memantau anakanaknya dalam Sekaa Teruna-Teruni sehingga ketika anakanaknya tidak ingin ikut kegiatan, orangtua dapat memberikan dorongan agar anak-anaknya tetap memiliki semangat untuk berpartisipasi.

Kepala desa sebagai pimpinan utama di desa diharapkan dapat memberikan pembinaan dan memantau setiap pelaksanaan kegiatan Sekaa Teruni-Teruni sehingga apabila ditemukan permasalahan dalam Sekaa Teruna-Teruni, kepala desa dapat bersama-sama membantu anggota Sekaa Teruna-Teruni untuk mengatasi permasalahan tersebut.

Pemerintah Kabupaten Badung yang sudah memiliki program untuk mengembangkan Sekaa Teruna-Teruni di Kabupaten Badung agar tetap melanjutkan program yang telah dirancang dan tetap memfasilitasi Sekaa Teruna-Teruni di Kabupaten Badung agar tetap berkembang. Pemerintah juga diharapkan dapat menampung aspirasi yang disampaikan oleh anggota Sekaa Teruna-Teruni sehingga solusi yang diberikan oleh pemerintah dapat meningkatkan kohesivitas pada anggota Sekaa Teruna-Teruni di Kabupaten Badung.

Bagi peneliti selanjutnya, disarankan agar mengetahui jumlah keseluruhan anggota di Sekaa TerunaTeruni yang menjadi sampel penelitian. Peneliti juga sebaiknya melakukan komunikasi yang baik dengan ketua Sekaa Teruna-Teruni sehingga ketua Sekaa Teruna-Teruni tersebut bisa mengetahui tujuan penelitian dengan baik dan dapat mengumpulkan anggotanya dengan jumlah yang cukup banyak. Pelaksanaan penelitian sebaiknya dilakukan saat Sekaa Teruna-Teruni tersebut melaksanakan kegiatan di Banjar karena dapat mempermudah dan mempercepat bertemu dengan anggota Sekaa Teruna-Teruni sehingga mempermudah dalam proses pengambilan data. Sumbangan efektif pada penelitian ini sebesar $72,3 \%$, sedangkan sisanya sebesar $27,7 \%$ dijelaskan oleh faktor lain. Peneliti selanjutnya yang ingin melakukan penelitian mengenai kohesivitas kelompok pada anggota Sekaa Teruna-Teruni diharapkan untuk menggunakan faktor lain yang mungkin memengaruhi kohesivitas kelompok dengan cara menambah jumlah variabel bebas penelitian untuk mendapatkan hasil yang lebih luas dan mendalam. Peneliti selanjutnya juga dapat melakukan uji lanjutan dari penelitian ini yang bertujuan untuk memprediksi kohesivitas kelompok dengan melibatkan faktor lama bergabung di Sekaa Teruna-Teruni, usia, pendidikan terakhir, dan banjar.

\section{DAFTAR PUSTAKA}

Abu, R. (1981). Sistem kesatuan hidup setempt daerah Bali. Denpasar: Departemen Pendidikan dan Kebudayaan Proyek Inventarisasi dan Dokumentasi Kebudayaan Daerah Bali.

Allen, N.J., \& Meyer, J.P. (1990) The measurement and antecedents of affective, continuance and normative commitment to the organization. The British Psychology Society, 63(1), 1-18.

Antara. (2017). 533 STT Badung dapat bantuan Rp 7,99 miliar. Diunduh dari https://metrobali.com/2017/01/23/533-sttbadung-dapatbantuan-rp799-miliar/

Arninda E.D.P., \& Safitri, R. M. (2003). Hubungan antara kohesivitas kelompok dengan motivasi kerja pegawai kelurahan di kecamatan kasihan kabupaten Bantul. Fakultas Psikologi Universitas Mercu Buana Yogyakarta, 1-10.

Azwar, S. (2010). Reliabilitas dan validitas. Yogyakarta: Pustaka pelajar. 


\section{HUBUNGAN ANTARA RASA KOMUNITAS DAN KOMITMEN ORGANISASI DENGAN KOHESIVITAS KELOMPOK}

Azwar, S. (2014). Reliabilitas dan validitas edisi 4. Yogyakarta: Pustaka pelajar.

Azwar, S. (2015). Penyusunan skala psikologi edisi 2. Yogyakarta: Pustaka Pelajar.

Corey, M.S., Corey, G., \& Corey, C. 2010. Groups: Process and practice (8th ed). USA. Wadsworth Cengange Learning.

Creswell, J. W. (2009). Research design: Qualitative, quantitative, and mixed method approaches (3rd ed.) (A. Fawaid, Trans.). Yogyakarta : Pustaka Pelajar.

Darwita, F.A. (2012). Hubungan antara kohesivitas kelompok pada kelompok peserta mentoring agama islam dengan tanggung jawab siswa SMA. Skripsi tidak dipublikasikan. Fakultas Psikologi, Program Sarjana Reguler, Depok.

Dwityanto, P., \& Amalia, P.A. (2012). Hubungan antara kohesivitas kelompok dengan komitmen organisasi pada karyawan. Providing Seminar Nasional Psikologi Islam, 270-276.

Field, A. (2009). Discovering statistic using SPSS (3rd ed.). London : SAGE Publications.

Forsyth, D.R. Grouph dynamic 5th edition. 2010. USA: Wadsworth Cengange Learning.

Greenberg, J. (2005). Managing behavior in organization. New Jersey: Pearson Printice Hall.

Ghozali, I. (2005). Aplikasi analisis multivariate dengan program SPSS. Semarang: Badan Penerbit Universitas Diponegoro.

Hurlock, E. B. (1980). Psikologi perkembangan: Suatu pendekatan sepanjang rentang kehidupan, Edisi 5. Jakarta: Erlangga.

Hutama, G.G. (2015). Hubungan antara kohesivitas kelompok dengan perilaku agresi pada kelompok suporter panser biru Semarang. Skripsi tidak dipublikasikan. Fakultas Psikologi Universitas Kristen Satya Wacana, Salatiga.

Kebudayaan Indonesia.(2014). Sekaa teruna-teruni .Diunduh dari http://kebudayaanindonesia.net/kebudayaan/838/sekaateruna-teruni.

Kloos, B., Hill, J., Thomas, E., Wandersman, A., Elias, M.J., \& Dalton, J.H. (2012). Community psychology: Linking individuals and communities (3rd ed). USA: Wadsworth Cengange Learning.

Kurniawati, F. (2016). Pengaruh kohesivitas kelompok dan kepuasan kerja terhadap organizational citizenship behavior (OCB) (studi pada karyawan tetap PT. Madubaru Bantul Yogyakarta). Jurnal Manajemen Bisnis Indonesia (JMBI), 5(2), 101-111.

Kusumaputri, E.S. (2015). Komitmen pada perubahan organisasi (perubahan organisasi dalam perspektif islam dan psikologi. Yogyakarta: Deepublish

Luthans. (2002). Performance and motivation. New York: Prentice Hall.

Martika, I. D. (2013). Studi deskriptif kohesivitas kelompok karyawan di Yayasan Nurul Hayat Surabaya. Calyptra: Jurnal Ilmiah Mahasiswa Universitas Surabaya, 2(2).

McMillan, D.W., \& Chavis, D.M. (1986). Sense of community: A definition and theory. Journal of Community Psychology, 14(1), 16-23.

McMillan, D.W. (1996). Sense of community. Journal of community psychology, 24(4), 315-325
Meyer, J.P., \& Allen, N.J. (1997). Commitment in the workpplace. USA: Sage Pub

Mulyono, A.E. (2016). Perbedaan komitmen organisasi para anggota lembaga kemahasiswaan universitas (LKU) di Universitas Kristen Satya Wacana (UKSW) ditinjau dari jenis kelamin. Skripsi tidak dipublikasikan. Fakultas Psikologi Universitas Kristen Satya Wacana, Salatiga.

Munandar, A.S. (2001). Psikologi industri dan organisasi. Depok: UIPress.

Nazir, M. (1999). Metode penelitian sosial. Jakarta: Erlangga.

Papalia, D.E., Olds, S.W., \& Feldman, R.D. (2008). Human development (10th). NewYork: McGraw-Hill.

Popo, G.P. (2017). Miris melihat fenomena sekaa teruna-teruni sekarang. Diunduh dari $\mathrm{http} / / / \mathrm{mbasic}$. facebook/com/popoguspopo?_e_pi_=7\%2CP AGE_ID10\%2c8665218750

Pramadani, A.B, \& Fajrianthi. (2012). Hubungan antara komitmen organisasi dengan kesiapan untuk berubah pada karyawan devisi enterprise service (DES) Telkom Ketintang Surabaya. Jurnal Psikologi Industri dan Organisasi, 1(3), 112-118.

Prayoga, Y. \& Herdiyanto, Y.K. (2014). Hubungan antara rasa komunitas dengan motivasi kerja pengurus subak. Jurnal Psikologi Udayana, 1(2), 372-380.

Purwaningtyastuti, Wismanto B., \& Suharsono M. (2012). Kohesivitas kelompok ditinjau dari komitmen terhadap organisasi dan kelompok pekerjaan. Kajian Ilmiah Psikologi, 2(1), 179-182.

Rimata, E.P. (2014). Pengaruh komitmen organisasi dan motivasi kerja terhadap kepuasan kerja karyawan PT. Pos Indonesia Yogyakarta. Skripsi tidak dipublikasikan. Program Studi Manajemen, Fakultas Ekonomi, Universitas Negeri Yogyakarta.

Robbins, S.P., \& Judge, A.E. (2008). Perilaku organisasi buku 1 edisi ke 12. Jakarta: Salemba Empat.

Sarwono, W.S. 2005. Psikologi sosial: Psikologi kelompok dan psikologi terapan. Jakarta: Balai Pustaka.

Santoso, S. (2010a). Statistik multivariat. Jakarta: PT Alex Media Komputindo.

Santoso, S. (2010b). Statistik nonparametrik konsep dan aplikasi dengan SPSS. Jakarta: PT Gramedia.

Santrock, J. W. (2007). Remaja. Jakarta: Penerbit Erlangga.

Sintari, N. (2015). Sekaa teruna-teruni, pacu kegairahan beragama yowana Bali. Diunduh dari http://nithahomework.blogspot .com/2015/08/sekaa-teruna-teruni-pacu-kegairahan.html

STT Bali. (2017). Foto diunduh dari @ stt.bali

Sudijono, A. (2012). Pengantar statistik pendidikan. Jakarta : PT RajaGrafindo Persada.

Sugiyono. (2014). Metode penelitian kuantitatif, kualitatif, dan kombinasi (mixed methods). Bandung: Penerbit Alfabeta.

Surya, I.M. (2017). Bupati Badung serahkan dana bantuan kreativitas stt. Diunduh dari https://m.antarabali.com/berita/103740/ bupati-badung-serahkan-dana-bantuan-kreativitas-stt.

Sutika, I.K. (2016). APBD kabupaten di Bali capai Rp 15,9 Triliun. Diunduh dari http://m.antarabali.com/berita/91953/apbdkabupaten-di-bali-capai-rp159-triliun 
Tanzaq, T. (2007). Komitmen organisasi ditinjau dari kepuasan kerja pada salesman. Skripsi tidak dipublikasikan. Fakultas Psikologi, Universitas Katolitk Soegijapranata, Semarang.

Taylor, S.E., Peplau, A.L., \& Sears, D.O. (2009). Psikologi sosial edisi ke 12. Jakarta: Kenacana

Teresia, N., \& Suyasa, P.T.Y.S. (2008). Komitmen organisasi dan organizational citizenship behavior pada karyawan call centre di PT X. Phronesis Jurnal Ilmiah Psikologi Industrri dan Organisasi, 10(2), 154-169.

Trihapsari, V.R., \& Nashori, F. (2011). Kohesivitas kelompok dan komitmen organisasi pada financial advisor asuransi "x" Yogyakarta. Proyeksi, 6(1), 12-20..

Utami, R. R. \& Purwaningtyastuti. (2010). Kohesivitas karyawan ditinjau dari gender dan bagian kerja. Prosiding Seminar Nasional Peran Budaya Organisasi Terhadap Efektivitas dan Efisiensi Organisasi, 61-73.

Vilayanti, E. (2016). Studi pendahuluan : Pengalaman menjadi anggota sekaa teruna-teruni. Badung: Tidak dipublikasikan.

Vilayanti, E. (2016). Studi pendahuluan : Permasalahan pada sekaa teruna-teruni. Badung: Tidak dipublikasikan.

Verawati, Y., \& Utomo, J. (2012). Pengaruh komitmen organisasi, partisipasi dan motivasi terhadap kinerja karyawan pada PT. Bank Lippo TBK cabang Kudus. Jurnal Analisis Manajemen. 5(2), 1-8.

Wighting, M. (2011). Measuring sense of community and percieved learning among alternative licensure candidates. Journal of The National Association for Lternative Certification. 6(1), 4-12.

Wijono, S. 2010. Psikologi industri \& organisasi: Dalam suatu bidang gerak psikologi sumber daya manusia edisi ke 1. Jakarta: Kencana.

Yudiatmaja, F. (2013). Analisis regresi dengan menggunakan aplikasi komputer statistik SPSS. Jakarta: PT. Gramedia Pustaka Utama.

Zulkifli, D., \& Yusuf, U. (2014). Hubungan kohesivitas kelompok dengan kinerja karyawan pada bagian pemasaran ekspor PT. Biofarma (persero). Providing Psikologi, 9-15. 